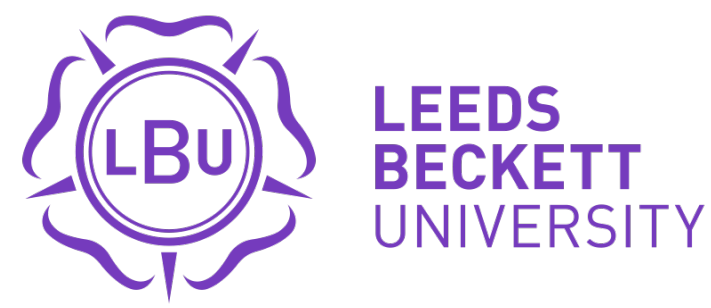

Citation:

Clifford, T and Babateen, A and Shannon, OM and Capper, T and Ashor, A and Stephan, B and Robinson, L and O'Hara, JP and Mathers, JC and Stevenson, E and Siervo, M (2018) Effects Of Inorganic Nitrate And Nitrite Consumption On Cognitive Function And Cerebral Blood Flow: A Systematic Review And Meta-Analysis Of Randomised Clinical Trials. Critical Reviews in Food Science and Nutrition. pp. 1-31. ISSN 1549-7852 DOI: https://doi.org/10.1080/10408398.2018.1453779

Link to Leeds Beckett Repository record:

https://eprints.leedsbeckett.ac.uk/id/eprint/4903/

Document Version:

Article (Accepted Version)

This is an Accepted Manuscript of an article published by Taylor \& Francis in Critical Reviews in Food Science and Nutrition on 10 July 2018, available online: http://www.tandfonline.com/10.1080/10408398.2018.1453779

The aim of the Leeds Beckett Repository is to provide open access to our research, as required by funder policies and permitted by publishers and copyright law.

The Leeds Beckett repository holds a wide range of publications, each of which has been checked for copyright and the relevant embargo period has been applied by the Research Services team.

We operate on a standard take-down policy. If you are the author or publisher of an output and you would like it removed from the repository, please contact us and we will investigate on a case-by-case basis.

Each thesis in the repository has been cleared where necessary by the author for third party copyright. If you would like a thesis to be removed from the repository or believe there is an issue with copyright, please contact us on openaccess@leedsbeckett.ac.uk and we will investigate on a case-by-case basis. 


\section{Effects Of Inorganic Nitrate And Nitrite Consumption On Cognitive Function And Cerebral Blood Flow: A Systematic Review And Meta- Analysis Of Randomised Clinical Trials}

Tom Clifford, Abrar Babateen, Oliver M Shannon, Tess Capper, Ammar Ashor, Blossom Stephan, Louise Robinson, John P O'Hara, John C. Mathers, Emma Stevenson \& Mario Siervo

To cite this article: Tom Clifford, Abrar Babateen, Oliver M Shannon, Tess Capper, Ammar Ashor, Blossom Stephan, Louise Robinson, John P O'Hara, John C. Mathers, Emma Stevenson \& Mario Siervo (2018): Effects Of Inorganic Nitrate And Nitrite Consumption On Cognitive Function And Cerebral Blood Flow: A Systematic Review And Meta-Analysis Of Randomised Clinical Trials, Critical Reviews in Food Science and Nutrition, DOI: 10.1080/10408398.2018.1453779

To link to this article: https://doi.org/10.1080/10408398.2018.1453779

View supplementary material ¿

Submit your article to this journal 지
Accepted author version posted online: 04 Apr 2018.

Џll Article views: 48

View Crossmark data \lceil 
Publisher: Taylor \& Francis

Journal: Critical Reviews in Food Science and Nutrition

DOI: https://doi.org/10.1080/10408398.2018.1453779

TITLE: EFFECTS OF INORGANIC NITRATE AND NITRITE CONSTIMPTION ON COGNITIVE FUNCTION AND CEREBRAL BLOOD FLOW: A STSTEMATIC REVIEW AND META-ANALYSIS OF RANDOMISED CLINICAL TRIALS

Authors: Tom Clifford ${ }^{1 \#}$, Abrar Babateen ${ }^{1,2 \#}$, Oliver M Shannon ${ }^{3}$, Tess Capper ${ }^{1}$, Ammar Ashor ${ }^{1,4}$, Blossom Stephan ${ }^{5}$, Louise Robinson ${ }^{5}$, John P O'Hara , Jokn C. Mathers ${ }^{1}$, Emma Stevenson $^{1}$ and Mario Siervo ${ }^{1}$

${ }^{1}$ Human Nutrition Research Centre, Institute of Celluiar Medicine, Newcastle University, William Leech Building, Newcastle on Tyne, NE2 4HH, UK

${ }^{2}$ Faculty of Applied Medical Sciences, Clinical Nutrition Department, Umm Al-Qura University, Makkah, Saudi Arabia

${ }^{3}$ Research Institute for Sport, Physical Activity. and Leisure, Leeds Beckett University, Leeds, $\mathrm{UK}$

${ }^{4}$ College of Medicine, University of A1-Mustansiriyah, Baghdad, Iraq

${ }^{5}$ Institute of Health and Society, New castle University, Newcastle upon Tyne, UK

Running title: Dietary nitrate, cognition and cerebral blood flow: A meta-analysis

Keywords: Inorganic Nitrate, Nitrite, Cognitive Function, Nitric Oxide, cerebral blood flow

*Corresponding author: Mario Siervo, Human Nutrition Research Centre, Institute of Cellular Medicine, Jswcastle University, William Leech Building, Newcastle on Tyne, NE2 4HH, UK. Eniail:mario.siervo@ncl.ac.uk.Tel: 01912481140

\#Shared First Name

The material presented in this manuscript is original and it has not been submitted for publication elsewhere while under consideration by Critical Reviews in Food Science and Nutrition 


\begin{abstract}
We conducted a systematic review and meta-analysis of randomized cinirical trials examining the effect of inorganic nitrate or nitrite supplementation on cognitive function (CF) and cerebral blood flow (CBF). Two databases (PubMed, Embase) were searchea for articles from inception until May 2017. Inclusion criteria were: randomized clinical trials; participants >18 years old; trials comparing a nitrate/nitrite intervention vith a control. Thirteen and nine trials were included in the meta-analysis to assess $\mathrm{CF}$ and CBF respectively. Random-effects models were used and the effect size described as standardized mean differences (SMDs). A total of 297 participants (median of 23 per rral) were included for CF; 163 participants (median of 16 per trial) were included for C $\mathrm{SB}$. Nitrate/nitrite supplementation did not influence CF (SMD +0.06, 95\% CI: $-0.06,0.18, \mathrm{P}=0.32$ ) or $\mathrm{CBF}$ under resting $(\mathrm{SMD}+0.14,95 \% \mathrm{CI}:-0.13,0.41, \mathrm{P}=0.31)$, or stimulatea conditions (SMD $+0.23,95 \% \mathrm{CI}:-0.11,0.56, \mathrm{P}=0.19$ ). The meta-regression showed an inverse association between duration of the intervention and $\mathrm{CBF}(\mathrm{P}=0.02)$ but no influence of age, BMI or dose $(\mathrm{P}<0.05)$. Nitrate and nitrite supplementation did not modify $\mathrm{CBF}$ of $\mathrm{CF}$. Further trials employing larger samples sizes and interventions with longer duration are warranted.
\end{abstract}




\section{Introduction}

Cognitive impairment and dementia are global health challenges becalse of the costs associated with management and treatment, severity of symptoms for the affected inuividual and impact on patients' families, carers and communities (Wortmann, 2012). Furtliermore, the prevalence of people diagnosed with dementia is rising at an alarning rate, with a recent report estimating that by 2050 the total number of individuals living with dementia worldwide will increase from 47 to 131 million (Prince et al., 2016). Therefore, effective interventions to prevent cognitive decline and dementia onset are a global research priority.

A major risk factor for cognitive decline is thought to be inadequate nitric oxide (NO) availability (de la Torie \& Stefano, 2000; Toda et al., 2009). NO is a free radical soluble gasotransmitter with pleiotropic actions, of which several are integral to normal cognitive function (CF), including regional blood flow, immune-surveillance, metabolic efficiency, glucose ho:neostasis, and neurotransmission (Toda et al., 2009; Weitzberg \& Lundberg, 2013). NO availability is determined by the activity of NO synthases (NOS), which are widely distributed across tissues in different isoforms (endothelial, inducible, neuronal) (Lundberg et al., 2008; Weitzberg \& Lundberg, 2013). In cognitive decline, NO generation via these pathways 
becomes dysregulated resulting in chronic hypo-perfusion, neurodegeneration and impaired cognitive ability (de la Torre \& Stefano, 2000; Toda et al., 2009).

NO can also be produced by a distinct alternative pathway involving the conversion of nitrate into nitrite and NO via a series of reducing reactions (Lundberg et al., 2008; Zweier et a1, 1995). Both nitrate and nitrite are present in a wide range of concentrations in a variety of foods with the higher content found in green leafy vegetables, beetroot, or meat products that have had nitrite salts added as preservatives (Lidder \& Webb, 2013). In the past cecade, it has emerged that increasing nitrate and nitrite ingestion may improve vascular and metabolic outcomes via increased generation of NO (Weitzberg \& Lundberg, 2013) More recent evidence also indicates potentially beneficial effects of both compounds, administered as ionic salts or nitrate-rich food products, on cognition and brain metabolic and vascular heaith (Clifford et al., 2015; Gilchrist et al., 2014; Justice et al., 2015; Presley et al., 2011, Wigntman et al., 2015). Such effects could be due to improved NO-mediated synaptic activity and/or as a consequence of increased cerebral blood flow (CBF) and thus a better coupling of blood flow to metabolism (Presley et al., 2011; Toda et al., 2009; Aamand et ail., 2013).

Mechanistic support for the latter hypothesis in humans has been provided by Presley and colleagues (2011), who observed that a diet rich in nitrate-containing foods (e.g., green leafy vegetaoles) stimnated cerebral perfusion in the prefrontal cortex of elderly adults, the region of the brain associated with executive function, working memory, and other processes reliant on cogntive ability. However, subsequent studies measuring $\mathrm{CBF}$, or directly measuring $\mathrm{CF}$, after inorganic nitrate or nitrite ingestion have produced mixed findings, possibly because of the small size and diversity of study designs employed (Clifford et al., 2015; Kelly et al., 2013). Thus, despite the therapeutic potential, it remains unclear whether augmenting NO bioavailability with 
either nitrite salts or nitrate-rich foods is an effective strategy for increasing CBF and/or mitigating cognitive deficits.

Consequently, we undertook a systematic review and meta-analysis of randomised clinical triais (RCTs) examining the efficacy of inorganic nitrate and nitrite supplementation on CBF and CE in adult participants with and without medical conditions. We set out to determine whether the ingestion of nitrite-salts or nitrate-rich foods (i.e., beetroot, spinach, rocket lettuce, cabbage; Lidder \& Webb, 2013) augments CBF and improves CF and to estimate effect sizes. We also examined whether test conditions (e.g., exercise vs. rest), age, body mass index (BMI), supplement dose, quality of the studies and intervention duration modified the effects of inorganic nitrate or nitrite on $\mathrm{CBF}$ and $\mathrm{CF}$. These results vill he! to inform whether nitrate or nitrite supplementation holds promise as a relatively irexpensive strategy for augmenting CBF and combatting cognitive decline.

\section{Methods}

The present systematic review was conducted according to the Cochrane guidelines and it is reported according to PRiSMA guidelines (Higgins \& Green, 2011; Liberati et al., 2009). The protocol of the systenatic review is available on request.

Literature search: Two databases (PubMed, Embase) were searched for articles from inception until May 2017. In addition, included reviews and eligible full text articles were searched manually to identify other suitable articles to be included in the systematic review. The following tarms and keywords were entered and Boolean terms were used to increase sensitivity of the search strategy: nitrate, nitrite, beetroot, rocket, cabbage, lettuce, spinach, green leafy vegetables, cognition, brain, dementia, cerebral, memory, executive, attention, motor skills, blood flow, 
vascular flow, perfusion. A summary of the specific search algorithms is reported in the Online Supplementary Material (Box 1).

Study selection: Titles and abstracts were screened using pre-defined eligibility criteria in accordance with the PICOS (population, intervention, comparator, outcome, study design) framework (Table S1 of the Online Supplementary Material) before retrieval of the fuil-text articles. The following inclusion criteria were used to assess the eligibility of aticles for inclusion in this systematic review: 1) randomised controlled trials (no exclusion criteria were used for study design, or blinding); 2) trials recruiting adult participants ( $\geq 18$ years) and no exclusion criteria were applied in relation to participants' health status; 3) trials based on nitrate or nitrite supplementation were included if they provide information on the type of nitrate salt (potassium or sodium), dose, formulation, frequency and route of administration. A list of .the inclusion and exclusion criteria is provided in the Qniine Supplementary Material (Box 2). Trials based on beet root juice supplementation or ingestion of nitrate-rich foods were included in the analyses if they provided information on the frequency and amount of nitrate-containing food provided; 4) trials reporting eifects of nitrate or nitrite on global and domain-specific CF and CBF measured by different techniques including magnetic resonance imaging (MRI), ultrasound or near infrared spectroscopy (NIRS); 5) English-language restriction but not time restriction was applied in searching the databases; 6) Full text papers and abstracts were included (if they contained sufficient information to complete qualitative and quantitative analysis). Two inve tigators (TC, OS) independently evaluated the titles and abstracts to check eligibility for inclusion. If the reviewers agreed, each article was either excluded or moved to the next stage (full-text). If agreement was not achieved, the article was moved for evaluation after retrieval of the full-text. The selected full-texts were then reviewed to confirm their inclusion in the 
systematic review. Disagreements were discussed with a third reviewer (MS) and resolved by consensus.

Data extraction: Relevant information was extracted and tabulated separately for CF and CBF. If information was not available from the full text, authors were contacted to obtain the relevant data.

Cognitive function: The following information was extracted independently by two investigators ( $\mathrm{AB}, \mathrm{TC})$ from eligible articles: 1) authors and year of publication; 2) study characteristics (design, sample size); 3) participant characteristics (age, male/female ratio, health status and baseline values for BMI; 4) route, dose and duration of inorganic nitrate and nitrite supplementation; and 5) cognitive tests and exercise condition. Any disagreements in data extraction were resolved through discussion until conserisus was reached.

Cerebral blood flow: Two independent reviewsrs (AB, MS) extracted relevant information from the eligible articles: 1) authors and year of publication; 2) study characteristics (design, sample size); 3) participarit characteristics (age, male/female ratio, health status and baseline values for BMI, and 4route, dose and duration of inorganic nitrate/ nitrite supplementation 5) method to ass ess cerebral blood flow (CBF) and testing conditions (i.e., exercise, mental stimulaticn). Any disagreements in data extraction were resolved through discussion until conserisus was reached.

Quaitity Assessment: The modified Jadad score was applied to evaluate the risk of bias of the trials. Specific questions linked to randomisation procedure, blinding and description of dropout or attrition rates were used rank the quality of the trials (Jadad et al., 1996). Scores ranged from 0 
to 5; a score less than 3 indicates a low quality trial where a score greater or equal to 3 indicates high quality trial.

\section{Statistical Analysis}

The primary outcomes of the meta-analysis were changes in CF and CBF after inorganic nitraie or nitrite supplementation. Random effect models were applied to address the neterogeneity related to differences in study design and application of different and concomitarit methods for the evaluation of $\mathrm{CF}$ and $\mathrm{CBF}$. In addition, some trials used several cognitive tests to assess domain-specific changes in CF and CBF, as shown in Table 1 and 2. This may lead to reduced independence of measurements and to consequential over-estimation of the effect size derived from the meta-analysis. These methodological aspects were taken into account into the analysis by averaging the standardised effect sizes for each frial with the aim of providing a more conservative estimate of the effect size. Forest poots were created to summarise and illustrate the individual and overall effects of inorganic nitrate and nitrite supplementation on $\mathrm{CF}$ and $\mathrm{CBF}$. The meta-analysis was conducted using Comprehensive Meta-Analysis software (Biostat, Engelwood, New Jersey). Results are described as standardized mean differences (SMDs) and $95 \%$ confidence intervals $(95 \% \mathrm{CI})$. If data were not available in the main text or in tables, figures were wed io extract the information.

Sensitivity analyses were performed to investigate whether the effects of inorganic nitrate and nitrite supplementation on $\mathrm{CF}$ and $\mathrm{CBF}$ were influenced by testing conditions (i.e., exercise or mental stimulation). A random-effect meta-regression model was applied to examine the associations between effect sizes for $\mathrm{CF}$ and for $\mathrm{CBF}$ and age, BMI, dose of nitrate/nitrite supplementation, duration of the trial and Jadad score. Funnel plots and Egger's regression tests 
were performed to evaluate the publication bias (Egger et al., 1997). Heterogeneity was assessed by using Cochrane $\mathrm{Q}$ statistic; $\mathrm{P}>0.1$ indicates significant heterogeneity. The I2 test was utilised to assess heterogeneity across trials where a value $<25 \%$ indicates low risk, $25-75 \%$ indicates moderate risk, and $>75 \%$ indicates a high risk (Higgins et al., 2003).

\section{Results}

\section{Search results}

The screening process and the number of the stridies included in the systematic review are described in Figure 1. The initial search of the two electronic databases produced 12865 articles which was reduced to 5387 after the deletion of auplicates. No relevant studies were found by manual search of relevant reviews and studies. After the first title and abstract selection phase, 23 full-text articles were jaentified for further assessment and, from these, 18 trials were included in the systematic revicw. Thirteen trials and nine trials were included in the metaanalysis to investigate effects of nitrate and nitrite supplementation on CF and CBF, respectively.

\section{Cognitive Function}

Studies characteristics: The trials included in the systematic review reported on a total of 297 participants with a median of 23 (range 10-48) participants per trial. The median age of the participants was 36 (range $21-73$ ) years. The systematic review includes 2 parallel and 11 crossover trials and 12 of them were double-blind. Six of these studies included an exercise component as part of the protocol to evaluate the effects of dietary nitrate and nitrite on CF at 
rest and during exercise. The large majority (12 of 13 studies) supplemented with nitrate or nitrate-rich foods; eleven trials used beetroot and one trial used spinach as sources of inorganic nitrate, and one study supplemented with sodium nitrite (see Table 1). As placebo, eight trials used nitrate-depleted beetroot juice (Kelly et al., 2013; Gilchrist et al., 2014; Lefferts et al., 2515; Rattray et al., 2015; Thompson et al., 2015; Thompson et al., 2016; Vanhatalo et al., 2016; Shannon et al., 2017), one studied employed nitrite-free capsules (Justice et al., 2015), two trials combined apple and blackcurrant juice (Thompson et al., 2014; Whitman et al., 2015) and one study did not report information on the control group (Bondonno et al., 2014).

Participant health status and intervention duration: Two trials included patients with type 2 diabetes (T2DM) (Gilchrist et al., 2014; Shepherd et al., 2015), frour trials included middle-aged and older healthy participants (Kelly et al., 2013; Bordonno et al., 2014; Justice et al., 2015; Vanhatalo et al., 2016) and the remaining seven trials recruited young healthy participants (Table 1). The median BMI of the adults included in the trials was $24.6 \mathrm{~kg} / \mathrm{m}^{2}$ (range: 24.0 $30.8 \mathrm{~kg} / \mathrm{m}^{2}$ ). The duration of interventions ranged from 90 minutes to 10 weeks but ten trials (out of 13) had a duration less than 7 days. For nitrate supplementation studies, the median dose of inorganic nitrate provided was $7.2 \mathrm{mmol} /$ day (range: $2.9-12.8 \mathrm{mmol} /$ day); the trial using nitrite supplemented with 2,4 $\mathrm{mmol} / \mathrm{day}$ of sodium nitrite (Justice et al., 2015).

The gieatest source of heterogeneity in the CF trials was the type of cognitive assessment with 23 different tests being reported. Three trials used a single CF test (Rattray et al., 2015; Thompson et al., 2015; Vanhatalo et al., 2016) whereas one trial employed eight different CF tests (Lefferts et al., 2015). A summary of the distribution of cognitive tests per trial is provided in Table 1 whereas the frequency of application of each test across all the trials is summarised in Figure S1 of the Online Supplementary Material. 
Meta-analysis: Overall, inorganic nitrate or nitrite supplementation did not improve CF (SMD $+0.06,95 \%$ CI: $-0.06,0.18, \mathrm{P}=0.32$ ) and we observed no significant heterogeneity between studies (I2 = 0\%; P = 0.68) (Figure 2). However, the only study which supplemented healthy older individuals with inorganic nitrite for 10 weeks reported a significant improvement $1 \mathrm{n}$ CF (Justice et al., 2015). When stratified by inclusion of exercise testing in the protocols, there was no significant effect of inorganic nitrate supplementation in either the exercise $(N=6$, SMD $+0.13,95 \%$ CI: $-0.05,0.32, \mathrm{P}=0.16)$ or non-exercise $(\mathrm{N}=7, \mathrm{SMD}+0.02,95 \% \mathrm{CI}:-0.15,0.21, \mathrm{P}$ $=0.76)$ trials. Meta-regression analysis did not reveal any significant association between $\mathrm{CF}$ effect size and age ( $\beta$ : -0.002 , SE: 0.003, $\mathrm{P}=0.33$ ), BMI, ( $\beta$ : -0.02 , SE: $0.02, \mathrm{P}=0.23)$, dose ( $\beta$ : 0.002, SE: $0.004, P=0.63)$, study duration $(\beta: 0.0005$, SE: 0.002, $P=0.07)$ or Jadad score $(\beta$ : 0.09, SE: 0.18, $\mathrm{P}=0.09$ ) (Table 3).

Study Quality and Publication bias: The quality of the trials ranged from 2 to 5 (median: 3 ) on the Jadad score and only one study had a score $<3$ (Bondonno et al., 2014), indicating the overall high quality of the trials (Table 1). Visual inspection of the Funnel Plot revealed a study with a large positive effect size and the presence of publication bias was also confirmed by the Egger's Regression test ( $\mathrm{p}=0.01$; Figure S3 of the Online Supplementary Material). Exclusion of the study (Justree et al., 2015) with the largest positive effect size removed the publication bias ( $\mathrm{N}=12$ Egger's test, $\mathrm{P}=0.13)$.

\section{Resting and Stimulated CBF}

Studies characteristics: Nine trials assessed changes in CBF in resting conditions and included a total of 163 participants (sample size range: $10-40$ ); the overall median age of the participants was 22 years (range $20-70$ ). Five of these studies also assessed CBF under stimulated 
conditions (i.e., exercise (Bond et al., 2013; Curry et al., 2016; Lefferts et al., 2016; Thompson et al, 2014), or mental stimulation (Wightman et al., 2015)).

One study employed a parallel study design (Whitman et al., 2015) whereas all remaining eigfit trials used a cross-over design (Aamand et al., 2013; Bond et al., 2013; Chirinos et a1., 2017, Curry et al., 2016; Lefferts et al., 2016; Presley et al., 2011; Rattray et al., 2015; Thoinpson et al, 2014) (Table 2). Most studies (seven) used beetroot juice as a source of inorganic hitrate but high nitrate foods or sodium nitrite were also used in some studies (Tabjez).

Cerebral blood flow tests: Four studies reported the effect of inorganic nitrate supplementation on middle cerebral artery blood flow velocity (MCAV) (Aanand et al., 2013; Curry et al., 2016; Lefferts et al., 2016; Rattray et al., 2015) and two reperted the effect of inorganic nitrate on CBF measured by arterial spin labelling (Presley et al., 2011; Aamand et al., 2013). Additional measurements used to assess CBF included Near inirared Spectroscopy (Thompson et al, 2014; Whitman et al., 2015), cerebrnvascular resistance index by Transcranial Doppler Ultrasonography (Bond et al. 2013y and evaluation of changes in Carotid Characteristic Impedance, Carotid Cross-Sestional Area and Carotid Bed Vascular Resistance (Chirinos et al., 2017). The frequency of application of each method across all the trials is summarised in Figure S2 of the Online Supplementary Material.

Participant health status and intervention duration: Eight trials recruited healthy individuals and one trial recruited patients with heart failure (Chirinos et al., 2017) (Table 2). The duration of the inorganic nitrate supplementation ranged from 3 hours to 3 days. The dose of inorganic nitrate ranged from 5.5 to $24 \mathrm{mmol} /$ day (median dose: $9.8 \mathrm{mmol} / \mathrm{day}$ ). 
Meta-analysis: Overall, inorganic nitrate did not improve CBF under either resting (SMD +0.14, 95\% CI: $-0.13,0.41, \mathrm{P}=0.31$ ), or under stimulated conditions (SMD +0.23, 95\% CI: $-0.11,0.56$, $\mathrm{P}=0.19)$. We observed moderate heterogeneity between studies testing the effect of inorganic nitrate on $\mathrm{CBF}$ at rest and stimulated conditions $(\mathrm{I} 2=56.7 \% ; \mathrm{P}=0.01 ; \mathrm{I} 2=44.1 \% ; \mathrm{P}=-0.12$, respectively) (Figure 3). Meta-regression analysis produced no evidence for significant: associations of resting CBF effect size with age $(\beta$ : 0.001, SE: 0.006, $\mathrm{P}=0.98)$, BNil $(\beta .0 .016$, SE: $0.019, \mathrm{P}=0.41)$, dose $(\beta:-0.01$, SE: $0.019, \mathrm{P}=0.58)$, or Jadad score $(\beta: 0.03$, SE: $0.13, \mathrm{P}=$ 0.79). However, there was a significant negative association between CB ef ect size and study duration $(\beta$ : -0.001 , SE: 0.0006, $\mathrm{P}=0.02)$ (Table 3).

Study Quality and Publication bias: The quality of the trials ranged from 2 to 4 (median: 2) according to the Jadad score. On this scoring systern, 4 stusies showed a score $\geq 3$ (Chirinos et al., 2017; Lefferts et al., 2015; Thompson et al, 2014; Wighman et al., 2015) (Table 2). We could not assess the quality of one study (Ratiary et al., 2015), as it was an abstract. Visual inspection of the Funnel Plot revealed no evidence of publication bias and this was confirmed by the Egger's Regression tesi for both resting $(\mathrm{p}=0.43)$ and stimulated $\mid(\mathrm{p}=0.58)$ CBF; Figure S4 and S5 of the Online Suppiementary Material).

\section{Discussion}

Our meta-analysis revealed that inorganic nitrate or nitrite supplementation was not associated with improved CF or increased CBF. The combined standardized mean difference (placebo vs. intervention) was +0.06 for $\mathrm{CF}$ and +0.14 and +0.23 for $\mathrm{CBF}$ at rest and in simulated conditions, respectively. These findings were not influenced by whether the tests were performed at rest, during exercise or with mental stimulation, by the age or health status of the participants or by 
the dose of inorganic nitrate or nitrite. Overall, the studies had small sample sizes and were of short duration, making it difficult to draw definitive conclusions about the efficacy of inorganic nitrate or nitrite in modulating $\mathrm{CF}$ and $\mathrm{CBF}$.

The quality of the studies assessing CF was generally high; all studies employed a randomized design, used appropriate interventions, and in all but one of these studies (Bondonro et a1., 2014) the intervention agent was provided in a double-blind fashion. Similarly, with the exception of one study, those assessing effects on CBF were all randomized, crossoyer rials. However, only 6 of the 9 trials were double-blind so that (along with other factors) nieant they were generally of lower quality than those assessing effects on CF (Table 2). The overall utility of all the included trials was severely limited by the small sample sizes. Indeed, only 2 of the 21 studies reported that they had conducted an a priori power analysis to deterrnine if they had an adequate sample size to detect a treatment effect for CF or CBF. One of these studies (Bondonno et al., 2014), suggested that at $80 \%$ power, 30 participants vas sufficient to detect subtle treatment effects (e.g., $27 \mathrm{~ms}$ in simple reaction time) in yarious cognitive tasks. Given that the median sample size in the studies that assessed CF v as only 23 , it would be reasonable to assume that many of the studies were now adequately powered to detect potential effects of the nitrate or nitrite interventions. and that the risk of type 2 errors was high. In view of this, it is vitally important that future studies ir clude larger sample sizes and ensure they are sufficiently powered to detect anticipated nitrate/nitrite-induced changes in $\mathrm{CBF}$ or $\mathrm{CF}$.

The participants in most studies were of normal BMI, male, healthy, and not suffering from a cognitive-related disease. Of the two studies that examined effects of inorganic nitrate or nitrite on $\mathrm{CF}$ in a non-healthy cohort (T2DM patients), one observed improvements following the intervention (Gilchrist et al., 2014) and one did not (Shepherd et al., 2015). All remaining 11 
trials that investigated effects of nitrate/ nitrite supplementation on $\mathrm{CF}$ were performed in participants with a BMI $\leq 25 \mathrm{~kg} \cdot \mathrm{m}^{2}$. Because obesity is associated with impaired NO availability, it could be argued that individuals with a BMI $\geq 30 \mathrm{~kg} \cdot \mathrm{m}^{2}$ might be more responsive to nitrate or nitrite induced vascular or metabolic effects (Ashor et al., 2016). Conversely, consequent to their) greater body mass, it is possible that obese individuals will require a larger absolute nitrate/nitrite dose to manifest meaningful physiological changes. Prescribing a nitrate dose relaure te body mass could help ameliorate this issue. Future studies should compare the effects of nitrate or nitrite supplementation on CF in both normal weight and obese indiviunals. As for studies that assessed effects on $\mathrm{CF}$, only one study assessed effects of inerganic nitrate supplementation on CBF in non-healthy, obese participants. Chirinos and coilieagues (2017) examined the effects of nitrate-rich beetroot juice in heart failure patients, anc observed no significant changes in carotid artery hemodynamics. Arguably, older individiais suffering from a disease - especially a diagnosed cognitive disorder - are more likeiy to benefit from an intervention attempting to reestablish a dysfunctional pathway than young, healthy individuals, in whom NO availability is less likely to be impaired. Thas, it woyld seem prudent that future research prioritizes studying the effects of inorganic nitrate and nitrite supplementation on CF and CBF with older individuals with some cognitive dysfunction e.g. mild cognitive impairment or subjective memory complaints. In addition, few studies were carried out using female participants. Although there is no streng a priori rationale to anticipate that the impact of such supplementation would differ by scx, future studies should address potential effects in women.

Our meta-regression showed that the duration of the nitrate or nitrite supplementation had a modest influence on CBF. More specifically, the longer the duration of the supplementation, the smaller was the improvement in CBF. However, this observation should be interpreted with 
caution because the majority of the trials had a very short duration. Of the nine studies assessing effects on $\mathrm{CBF}$, only two provided the supplement for $>150 \mathrm{~min}$ pre-assessment — and both displayed positive effects. The first, by Presley et al., (2011), was a randomized crossover trial in which healthy older adults received either a low nitrate or high nitrate diet for 2 days piror to measurements of cerebral perfusion using magnetic resonance imaging (MRI). Those in the high. nitrate diet (12.6 mmol/day) group had a substantial and preferential increase in frontai cortex perfusion compared to those in the low nitrate diet group $(0.9 \mathrm{mmol} / \mathrm{day})$. The other study, by Aamand and colleagues, (2013) found that 3 days of sodium nitrate (vs nitrate-free saline) decreased the haemodynamic lag of the blood oxygenation levei dependent (BOLD) response in the visual cortex of healthy, young males (Table 2). However $\mathrm{CBF}$, as measured by MRI, was unchanged. Clearly, more studies with longer supplementation periods are required before we can establish whether duration moderates the efficacy of nitrate/nitrite on CBF.

Most of the studies provided nitrate in the form of beetroot juice or nitrate-rich foods such as green leafy vegetables. Given snly two studies assessed the effects of nitrate/ nitrite salts on CF or $\mathrm{CBF}$, it was not possible to exaniine whether the vehicle for nitrate delivery (i.e., nitrate salts or nitrate-rich vegefable products) influenced the efficacy of supplementation. Interestingly, however, compared with nitrate salts, recent studies have reported greater effects of nitrate-rich vegetable products on blood pressure (Jonvik et al., 2016), the oxygen cost of exercise (Flueck et al., 2015), and post-exercise recovery (Clifford et al., 2017). This suggests possible additive or syne gistic effects between nitrate and other plant-based compounds. Indeed, several plant-based compounds other than nitrate have potential benefits on CF and CBF (Ide et al., 2014; Desideri et al., 2012; Macready et al., 2009). These compounds include polyphenols, such as catechins, anthocyanins, and other flavonoids, and carotenoids (Macready et al. 2009; Gómez-Pinilla, 
2008) that are purported, at least in part, to exert their beneficial effects on $\mathrm{CBF}$ and $\mathrm{CF}$ through NO-dependent mechanisms, namely increased vasodilative effects (Sokolov et al., 2013). To our knowledge, there is no evidence to suggest that beetroot, the main vehicle used in the RCTs included in this analysis, contains high quantities of the polyphenolic compounds showing potential for cognitive modulation. Indeed, the most abundant bioactive compound in beetroot, other than nitrate, is betanin and, to date, its effects on cognitive function are unkriown. Notwithstanding, we acknowledge that the current evidence makes it impossible to differentiate the effects of nitrate/nitrite salts and nitrate-rich plants on cognitive function, the latter of which contains additional bioactive compounds. The independent effects of the bioactive compounds and the nitrate/nitrite in these foods is an important question for future research.

Our study also has a number of other limitations. Firstiy, because such a wide range of assessments and methods were used to evaluate CF several of which were domain-specific (e.g., reaction time vs. working memory), pooling the average effect size for all tests overlooks potential changes for isolated tests. This s illustrated by the fact that when each cognitive test was modelled as an independent outcome in the meta-analysis, nitrate supplementation showed a modest benefit for Cr (data not shown). Nonetheless, this latter finding, in which all tests are considered indeperidently, can overestimate the effect size; hence, to provide a more conservative escinate, we chose to use the average effect size from each study as our main outcone measure. Secondly, we observed moderate heterogeneity between studies for CBF, likely because of the wide variability in participant age and health status, CBF measures used, and the dose and duration of the nitrate/nitrite interventions used in each study. As outlined in a recent commentary (Barnard et al., 2017), heterogeneity between studies may disguise the benefits observed in single, well-controlled studies that, under specific conditions (e.g., dose, 
duration, population) demonstrated real effects. This possibility needs to be taken into consideration when interpreting our findings.

Conclusions: In conclusion, there is no robust evidence that inorganic nitrate or nitrate supplementation influences CBF or CF. However, these findings might not be generalizable tos older people, those with higher adiposity or and those with reduced cognitive ability, all of the included studies were performed in individuals $<75$ years old. In addition, all avaitable trials were characterized by small sample sizes and short intervention durations and, thus, most of the studies may not have been designed optimally to observe any potentiai henefits. Consequently, the main conclusion of this study is that there is insuficient evidence to know whether supplemental inorganic nitrate or nitrite could improve CF or enhance CBF. Given the interest in use of non-pharmacological approaches for maintenance and improvement of cognitive function during ageing and the mechanistic rationai for potential benefits of enhanced NO availability, further well-controlled and sufficiently powered trials, especially in more at-risk populations, with longer duration of nitrate/ nitrate supplementation, need to be conducted.

Acknowledgements: We would like to thank Dr Rattray for sharing the data from his studies.

Financial Disclosure: None reported. 
Funding/Support: The write up of this work was undertaken within the framework of the NIHR Global Group: DePEC (Grant Number: 16/137/62).

\section{References}

Aamand, R., Dalsgaard, T., Ho, Y, C., Moller, A., Roepstorff, A., and Lund, T, E, A. (2013). NO way to BOLD? Dietary nitrate alters the hemodynamic response to visual stimulation. Neuro Image. 83:397-407.

Ashor, A. W., Chowdhury, S., Oggioni, C., Dadır D., Brandt, K., Ishaq, A., and Siervo, M. (2016). Inorganic nitrate supplementation in young and old obese adults does not affect acute glucose and insulin responses but lowers oxidative stress. The Journal of Nutrition. 146: 22242232.

Barnard, N.D., Willeit, W.C. and Ding, E.L., (2017). The Misuse of Meta-analysis in Nutrition Research. JAMA. dor 10.1001/jama.2017.12083.

Bond, V Curry, B. H., Adams, R. G., Asadi, M. S., Millis, R. M., and Haddad, G. E. (2013). Effects ef dietary nitrates on systemic and cerebrovascular hemodynamics. Cardiology Research and Practice. doi: 10.1155/2013/435629. 
Bondonno, C. P., Downey, L. A., Croft, K. D., Scholey, A., Stough, C., Yang, X., ... and Mubarak, A. (2014). The acute effect of flavonoid-rich apples and nitrate-rich spinach on cognitive performance and mood in healthy men and women. Food \& Function. 5: 849-858.

Chirinos, J. A., Londono-Hoyos, F., Beraun, M., Haines, P., Izzah, V. M., Varakantam, S, and Segers, P. (2016). Effects of organic and inorganic nitrate on aortic and carotid hemodynamics in heart failure and preserved ejection fraction. doi: 10.1002/ejhf.885.

Clifford, T., Howatson, G., West, D. J., and Stevenson, E. J. (2015). The potentiai benefits of red beetroot supplementation in health and disease. Nutrients. 7: 2801-2822.

Clifford, T., Howatson, G., West, D. J., \& Stevenson, E. J. (2017). Beetroot juice is more beneficial than sodium nitrate for attenuating muscle pain after strenuous eccentric-bias exercise. Applied Physiology, Nutrition, and Metabolism. cioi. 10.1139/apnm-2017-0238.

Curry, B. H., Bond, V., Pemminati, S., Gorantia V. R., Volkova, Y. A., Kadur, K., and Millis, R. M. (2016). Effects of a Dietary Beetroot Juice Treatment on Systemic and Cerebral Haemodynamics-A Pilot Study. Journal of Clinical and Diagnostic Research. 10: CC01-CC05.

De la Torre, J. C., and Stefano, G. B. (2000). Evidence that Alzheimer's disease is a microvascular disorder: the role of constitutive nitric oxide. Brain Research Reviews. 34: 119136.

Desideri, G., Kwik-Uribe, C., Grassi, D., Necozione, S., Ghiadoni, L., Mastroiacovo, D., and Marini, C. (2012). Benefits in cognitive function, blood pressure, and insulin resistance through cocoa flavanol consumption in elderly subjects with mild cognitive impairment. Hypertension. 70. doi.org/10.1161/HYPERTENSIONAHA.112.193060. 
Egger, M., Smith, G. D., Schneider, M., and Minder, C. (1997). Bias in meta-analysis detected by a simple, graphical test. BMJ. 315: 629-634.

Flueck, J. L., Bogdanova, A., Mettler, S., and Perret, C. (2015). Is beetroot juice more effective than sodium nitrate? The effects of equimolar nitrate dosages of nitrate-rich beetroot juice and sodium nitrate on oxygen consumption during exercise. Applied Physiology, Nutrition, and Metabolism. 41: 421-429.

Gilchrist, M., Winyard, P. G., Fulford, J., Anning, C., Shore, A. C. and Benjamin, N. (2014). Dietary nitrate supplementation improves reaction time in type 2 diaietes: development and application of a novel nitrate-depleted beetroot juice placebo. Nitric Oxide. 40: 67-74.

Gómez-Pinilla, F. (2008). Brain foods: the effects of nutrients on brain function. Nature Reviews Neuroscience. 9: 568-578.

Higgins, J. P., Thompson, S. G., Deeks, J. J., and Altman, D. G. (2003). Measuring inconsistency in meta-analyses. $B M J .327: 557$.

Higgins, J. P., and Green, S (Eús.). (2011). Cochrane handbook for systematic reviews of interventions (Vgi. 4). John Wiley \& Sons.

Ide, K., Yarada, H., Takuma, N., Park, M., Wakamiya, N., Nakase, J., ... \& Sagesaka, Y. M. (2014). Green iea consumption affects cognitive dysfunction in the elderly: a pilot study. Nutricnts. 6: 4032-4042.

Jadad, A. R., Moore, R. A., Carroll, D., Jenkinson, C., Reynolds, D. J. M., Gavaghan, D. J., and McQuay, H. J. (1996). Assessing the quality of reports of randomized clinical trials: is blinding necessary? Controlled Clinical Trials. 17: 1-12. 
Jonvik, K. L., Nyakayiru, J., Pinckaers, P. J., Senden, J. M., van Loon, L. J., \& Verdijk, L. B. (2016). Nitrate-rich vegetables increase plasma nitrate and nitrite concentrations and lower blood pressure in healthy adults. The Journal of Nutrition. 146: 986-993.

Justice, J. N., Gioscia-Ryan, R. A., Johnson, L. C., Battson, M. L., de Picciotto, N. E., Beck, H. J., ... and Seals, D. R. (2015). Sodium nitrite supplementation improves motor function and skeletal muscle inflammatory profile in old male mice. Journal of Applied Physislogy. 118: 163169.

Kelly, J., Fulford, J., Vanhatalo, A., Blackwell, J. R., French, O., Bailey, S. J., ... and Jones, A. M. (2013). Effects of short-term dietary nitrate supplementation en biood pressure, O 2 uptake kinetics, and muscle and cognitive function in older adults. American Journal of PhysiologyRegulatory, Integrative and Comparative Physiology. 394: 73-83.

Larsen, F. J., Schiffer, T. A., Borniquel, S., Sanlin, K., Ekblom, B., Lundberg, J. O., and Weitzberg, E. (2011). Dietary ino ganic nitrate improves mitochondrial efficiency in humans. Cell Metabolism. 13: 149-15\%.

Lefferts, W. K., Hughes, W E., White, C. N., Brutsaert, T. D., and Heffernan, K. S. (2015). Effect of acute nitrate supplementation on neurovascular coupling and cognitive performance in hypoxia. Applied Physiology, Nutrition, and Metabolism. 41: 133-141.

Liberatı, 1. Altman, D. G., Tetzlaff, J., Mulrow, C., Gøtzsche, P. C., Ioannidis, J. P., ... and Moher, D. (2009). The PRISMA statement for reporting systematic reviews and meta-analyses of studies that evaluate health care interventions: explanation and elaboration. PLoS Medicine. 6: https://doi.org/10.1371/journal.pmed.1000100. 
Lidder, S., and Webb, A. J. (2013). Vascular effects of dietary nitrate (as found in green leafy vegetables and beetroot) via the nitrate- nitrite- nitric oxide pathway. British Journal of Clinical Pharmacology. 75: 677-696.

Lundberg, J. O., Weitzberg, E., and Gladwin, M. T. (2008). The nitrate-nitrite-nitric oxides pathway in physiology and therapeutics. Nature reviews. Drug discovery. 7: 156-167.

Macready, A. L., Kennedy, O. B., Ellis, J. A., Williams, C. M., Spencer, J. F., and Bứler, L. T. (2009). Flavonoids and cognitive function: a review of human rardonitzed controlled trial studies and recommendations for future studies. Genes \& Nutrition. 4: 227-242.

Presley, T. D., Morgan, A. R., Bechtold, E., Clodfelter, W., Dへve, R. W., Jennings, J. M., ... and Burdette, J. H. (2011). Acute effect of a high nitrate diet on brain perfusion in older adults. Nitric Oxide. 24: 34-42.

Prince, M., Comas-Herrera, A., Knann M., Guetchet, M., and Karagiannidou, M. (2016). World Alzheimer report 2016: improving healthcare for people living with dementia: coverage, quality and costs now and in the future.

Rattray, B., Egle Marshall, I., Northey, J., Hone, S., Smee, D., and Brassard, P. (2015). Dietary Nitrate improves Cerebral Perfusion, in Young Adults during Exercise: Relationship to Cognitive Performance. The FASEB Journal. 29(1 Supplement): 989.

Shannon, O. M., Duckworth, L., Barlow, M. J., Deighton, K., Matu, J., Williams, E. L., ... and Q'Hara, J. P. (2017). Effects of Dietary Nitrate Supplementation on Physiological Responses, Cognitive Function, and Exercise Performance at Moderate and Very-High Simulated Altitude. Frontiers in Physiology. 8: 401. 
Shepherd, A. I., Gilchrist, M., Winyard, P. G., Jones, A. M., Hallmann, E., Kazimierczak, R., ... and Wilkerson, D. P. (2015). Effects of dietary nitrate supplementation on the oxygen cost of exercise and walking performance in individuals with type 2 diabetes: a randomized, doubleblind, placebo-controlled crossover trial. Free Radical Biology and Medicine. 86: 200-208.

Sokolov, A. N., Pavlova, M. A., Klosterhalfen, S., \& Enck, P. (2013). Chocolate arid the brain: neurobiological impact of cocoa flavanols on cognition and behavior. Neuroscience \& Biobehavioral Reviews. 37: 2445-2453.

Thompson, K. G., Turner, L., Prichard, J., Dodd, F., Kennedy, D. Q., Haskell, C., ... and Jones, A. M. (2014). Influence of dietary nitrate supplementation on nhysiological and cognitive responses to incremental cycle exercise. Respiratory Physiclogy \& Neurobiology. 193: 11-20.

Thompson, C., Wylie, L. J., Fulford, J., Kelly, J., Blaci. M. I., McDonagh, S. T., ... and Jones, A. M. (2015). Dietary nitrate improves sprint performance and cognitive function during prolonged intermittent exercise. European journal of Applied Physiology. 115: 1825-1834.

Thompson, C., Vanhatalo. A., Jell, H., Fulford, J., Carter, J., Nyman, L., ... and Jones, A. M. (2016). Dietary nitrate supplementation improves sprint and high-intensity intermittent running performance. Nitric Cxide. 61. 55-61.

Toda, N., Ayajiki, K., and Okamura, T. (2009). Cerebral Blood Flow Regulation by Nitric Oxide- Recent Advances. Pharmacol Rev. 61:62-97.

Vanhatalo, A., Bailey, S. J., Blackwell, J. R., DiMenna, F. J., Pavey, T. G., Wilkerson, D. P., ... and Jones, A. M. (2010). Acute and chronic effects of dietary nitrate supplementation on blood pressure and the physiological responses to moderate-intensity and incremental exercise. 
American Journal of Physiology-Regulatory, Integrative and Comparative Physiology. 299: $1121-1131$.

Vanhatalo, A., Kelly, J., Winyard, P. G., Fulford, J., and Jones, A. M. (2016). Dietary Nitrate Reduces Blood Pressure And Improves Walking Economy And Cognitive Function In Oide: People. Medicine and Science in Sports and Exercise. 48(5 Suppl 1): 257.

Weitzberg, E., and Lundberg, J. O. (2013). Novel aspects of dietary nitrate and human health. Annual Review of Nutrition. 33: 129-159.

Wightman, E. L., Haskell-Ramsay, C. F., Thompson, K. G., Biackwell, J. R., Winyard, P. G., Forster, J., ... and Kennedy, D. O. (2015). Dietary nitrate nodulates cerebral blood flow parameters and cognitive performance in humans: a double-biind, placebo-controlled, crossover investigation. Physiology \& Behavior. 149: 149-158.

Wortmann, M. (2012). Dementia: a global heaith priority-highlights from an ADI and World Health Organization report. Alzheimer's Research \& Therapy. 4: 40.

Zweier, J. L., Wang. P., Samouilov, A., and Kuppusamy, P. (1995). Enzyme-independent formation of nitric oxide in biological tissues. Nature Medicine. 1: 804-809. 


\section{Figure Legends}

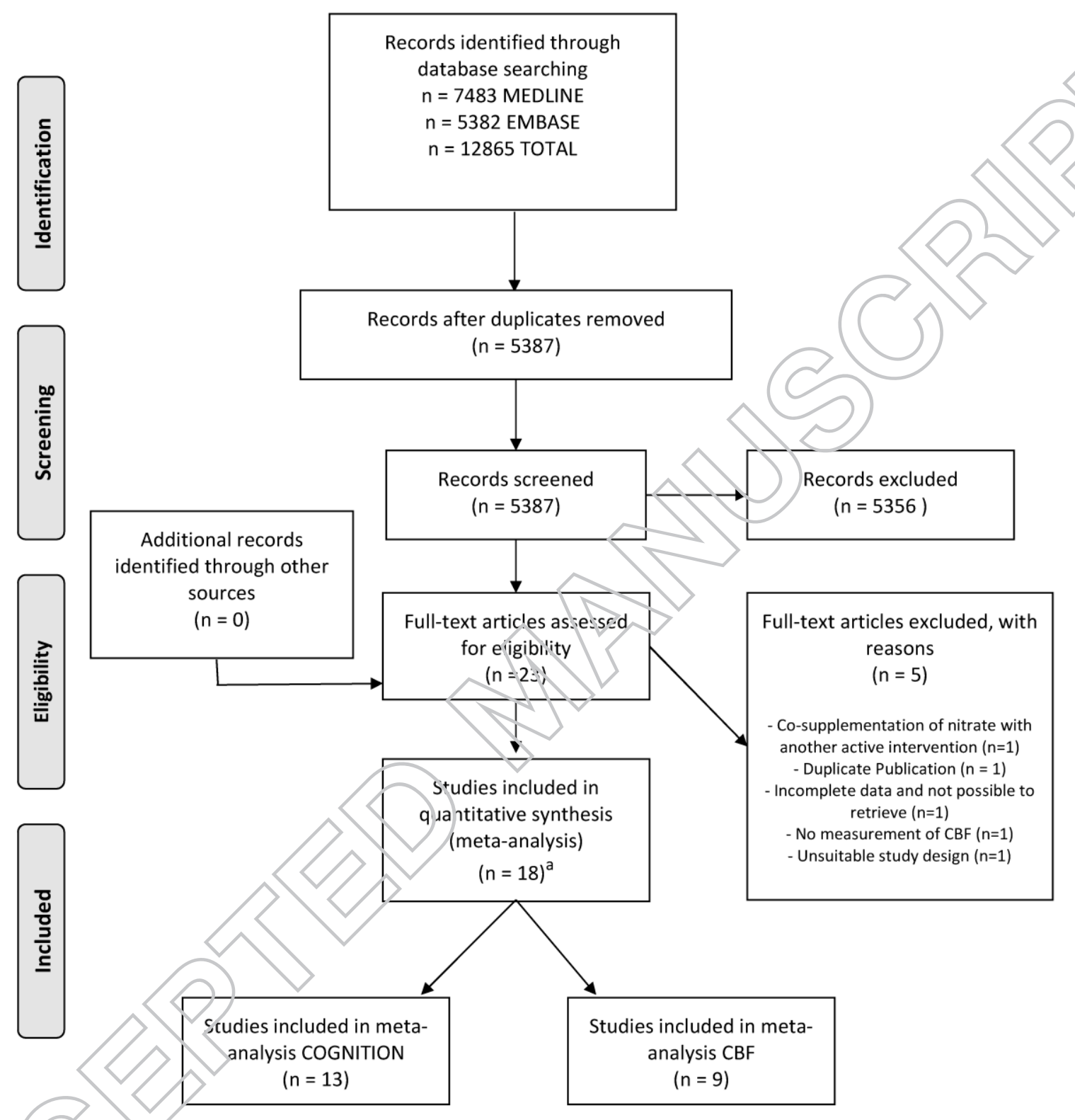

Figure 1: Flow diagram of the process used in selection of the randomised controlled trials included in this systematic review and meta-analysis 


\begin{tabular}{llrccr} 
Study name & Subgroup within study & \multicolumn{5}{c}{ Statistics for each study } \\
\cline { 3 - 7 } & & $\begin{array}{r}\text { Std diff } \\
\text { in means }\end{array}$ & $\begin{array}{c}\text { Lower } \\
\text { limit }\end{array}$ & $\begin{array}{c}\text { Upper } \\
\text { limit }\end{array}$ & p-Value \\
Bondonno, 2015 & No Exercise & -0.10 & -0.46 & 0.26 & 0.60 \\
Gilchrist, 2014 & No Exercise & 0.03 & -0.35 & 0.41 & 0.89 \\
Justice, 2015 & No Exercise & 0.96 & 0.03 & 1.89 & 0.04 \\
Kelly, 2012 & No Exercise & -0.10 & -0.68 & 0.47 & 0.72 \\
Lefferts, 2015 & Exercise & 0.17 & -0.28 & 0.62 & 0.46 \\
Rattray, 2015 & Exercise & 0.28 & -0.32 & 0.87 & 0.3 \\
Shannon, 2017 & Exercise & 0.05 & -0.57 & 0.67 & 0.88 \\
Shepherd, 2014 & No Exercise & -0.16 & -0.45 & 0.12 & 0.27 \\
Thompson, 2014 & Exercise & 0.00 & -0.49 & 0.49 & 1.00 \\
Thompson, 2015 & Exercise & 0.15 & -0.36 & 0.65 & 0.57 \\
Thompson, 2016 & Exercise & 0.16 & -0.17 & 0.49 & 0.35 \\
Vanhatalo, 2016 & No Exercise & 0.18 & -0.19 & 0.54 & 0.34 \\
Wightman, 2015 & No Exercise & 0.32 & -0.32 & 0.95 & 0.33 \\
& & 0.06 & -0.06 & 0.18 & 0.32
\end{tabular}

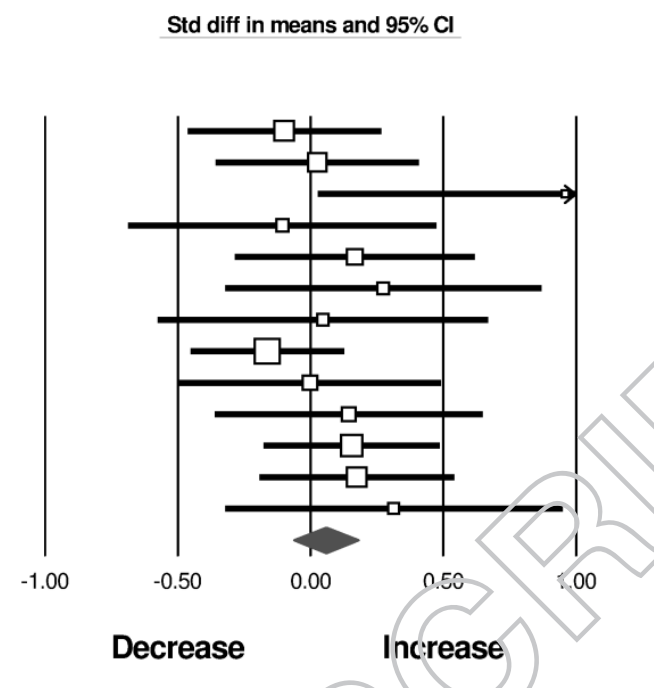

Figure 2: Forest plots showing the effect of dietary nitrate and nitrite suppiementation on cognitive function. 
Study name Subgroup within study Statistics for each study Std diff Lower Upper in means limit limit $p$-Value

Aamand, 2013 No Exercise

Bond, 2013 Exercise

Chirinos, 2017 No Exercise

Curry, 2016 Exercise

Lefferts, 2016 Exercise

Presley, $2011 \quad$ No Exercise

Rattray, $2015 \quad$ No Exercise

Thompson, 2014 Exercise

Wightman, 2015 No Exercise $\begin{array}{llll}-0.46 & -0.92 & 0.00 & 0.05\end{array}$

$\begin{array}{llll}0.64 & 0.08 & 1.19 & 0.02\end{array}$

$\begin{array}{llll}0.19 & -0.29 & 0.67 & 0.45\end{array}$

$\begin{array}{llll}-0.38 & -1.02 & 0.26 & 0.25\end{array}$

$\begin{array}{llll}-0.03 & -0.47 & 0.42 & 0.91\end{array}$

$\begin{array}{llll}0.10 & -0.43 & 0.63 & 0.71\end{array}$

$\begin{array}{llll}0.57 & -0.04 & 1.18 & 0.07\end{array}$

$\begin{array}{llll}0.67 & 0.12 & 1.21 & 0.02\end{array}$

$\begin{array}{llll}0.02 & -0.60 & 0.64 & 0.94\end{array}$

$\begin{array}{llll}0.14 & -0.13 & 0.41 & 0.31\end{array}$
Std diff in means and $95 \% \mathrm{Cl}$

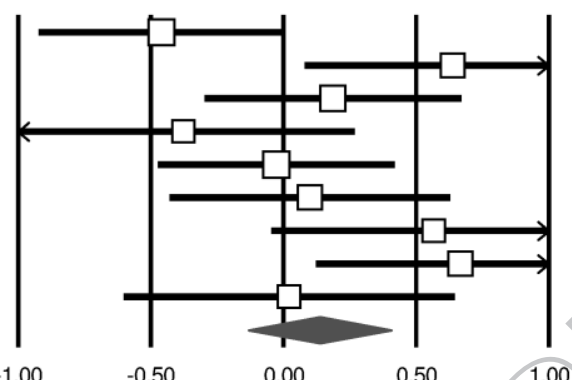

$0.00 \quad 0.50$

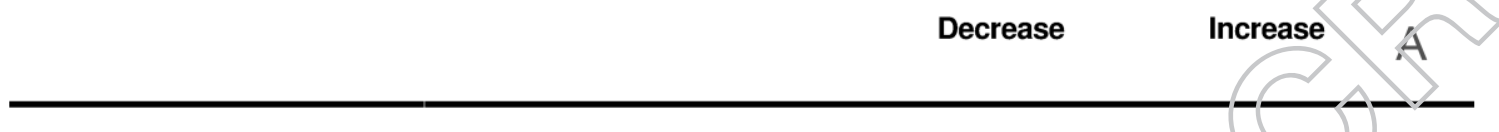

Study name Subgroup within study Statistics for each study

in means limit limit $p$-Value

Bond, $2013 \quad$ Exercise

Curry, 2016 Exercise

Lefferts, 2016 Exercise

Thompson, 2014 Exercise

Wightman, 2015 No Exercise

$\begin{array}{rrrr}0.60 & -0.01 & 1.22 & 0.06 \\ 0.18 & -0.45 & 0.80 & 0.58 \\ -0.09 & -0.54 & 0.35 & 0.68 \\ 0.65 & 0.11 & 1.19 & 0.02 \\ -0.15 & -0.77 & 0.47 & 0.64 \\ 0.23 & -0.11 & 0.56 & 0.19\end{array}$

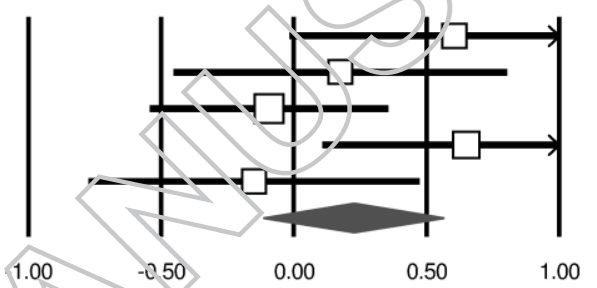

Decrease

Increase

B

Figure 3: Forest plots showing the effect of dietary nitrate and nitrite supplementation on cognitive function, cerebral blood flow at rest (A) and in stimulated conditions (B). 
Table 1: Characteristics of the studies included in the systematic review and meta-analysis of the effects of dietary nitrate/nitrite on cognitive function

\begin{tabular}{|c|c|c|c|c|c|c|c|c|c|c|c|c|c|c|}
\hline $\begin{array}{l}\text { Autho } \\
\mathrm{r} \\
\text { (year) }\end{array}$ & $\begin{array}{l}\text { Co } \\
\text { unt } \\
\text { ry }\end{array}$ & $\begin{array}{l}\text { Stud } \\
\text { y } \\
\text { Desi } \\
\text { gn }\end{array}$ & $\begin{array}{l}\text { Sam } \\
\text { ple } \\
\text { Size }\end{array}$ & $\begin{array}{l}\text { Health } \\
\text { Status }\end{array}$ & $\begin{array}{l}\text { Age } \\
\text { (yea } \\
\text { rs) }\end{array}$ & $\begin{array}{l}\text { M } \\
\text { al } \\
\text { es }\end{array}$ & $\begin{array}{l}\text { Nitrate } \\
\text { Dose } \\
\text { (mmol/d } \\
\text { ay) }\end{array}$ & $\begin{array}{l}\text { Type } \\
\text { of } \\
\text { Interve } \\
\text { ntion }\end{array}$ & $\begin{array}{c}\mathrm{Pl} \\
\mathrm{ac} \\
\mathrm{eb} \\
\mathrm{o}\end{array}$ & $\begin{array}{l}\text { Duration } \\
\text { of } \\
\text { intervent } \\
\text { ion }\end{array}$ & $\begin{array}{c}\text { Base } \\
\text { line } \\
\mathrm{BMI} \\
(\mathrm{Kg} / \\
\left.\mathrm{m}^{2}\right)\end{array}$ & Cognitive Tests & $\begin{array}{l}\text { Exerci } \\
\text { se } \\
\text { Testin } \\
\text { g? }\end{array}$ & $\begin{array}{c}\mathrm{Ja} \\
\mathrm{d}\end{array}$ \\
\hline $\begin{array}{l}\text { Bond } \\
\text { onno, } \\
2014\end{array}$ & $\begin{array}{c}\mathrm{Au} \\
\text { str } \\
\text { ali } \\
\mathrm{a}\end{array}$ & $\begin{array}{l}\mathrm{CO}, \\
\mathrm{R}, \\
\mathrm{UB}\end{array}$ & 30 & $\begin{array}{l}\text { Healthy } \\
\text { Middle- } \\
\text { Aged }\end{array}$ & $\begin{array}{c}47 . \\
3\end{array}$ & 6 & 2.9 & SP & - & $150 \mathrm{~min}$ & 23.6 & $\begin{array}{r}\text { SRT, DV, } \\
\text { CRT, SM!, } \\
\text { NWM, JW }\end{array}$ & & \\
\hline $\begin{array}{l}\text { Gilchr } \\
\text { ist, } \\
2014 \\
\end{array}$ & $\begin{array}{l}\mathrm{U} \\
\mathrm{K}\end{array}$ & $\begin{array}{l}\mathrm{DB}, \\
\mathrm{CO}, \\
\mathrm{R}, \mathrm{Pl}\end{array}$ & 27 & T2DM & $\begin{array}{c}67 . \\
2\end{array}$ & $\begin{array}{l}1 \\
8\end{array}$ & 7.5 & BJ & $\begin{array}{l}\mathrm{N} \\
\mathrm{D}- \\
\mathrm{BJ}\end{array}$ & 14 days & 30.8 & $\begin{array}{c}\text { SRT, SM, } \\
\text { RVIP, DPT, } \\
\text { SPM } \\
\end{array}$ & $\mathrm{NO}$ & 3 \\
\hline $\begin{array}{l}\text { Justic } \\
\text { e, } \\
2015\end{array}$ & $\begin{array}{c}\text { US } \\
\text { A }\end{array}$ & $\begin{array}{l}\mathrm{DB}, \\
\mathrm{P}, \mathrm{Pl}, \\
\mathrm{R}\end{array}$ & 30 & $\begin{array}{l}\text { Healthy } \\
\text { Older }\end{array}$ & 62 & $\begin{array}{l}1 \\
6\end{array}$ & $1.2 / 2.4$ & $\mathrm{SN}$ & $\begin{array}{l}\mathrm{N} \\
\mathrm{F}- \\
\mathrm{C}\end{array}$ & $\begin{array}{c}10 \\
\text { weeks }\end{array}$ & & TMTA & $\mathrm{NO}$ & 4 \\
\hline $\begin{array}{l}\text { Kelly, } \\
2013\end{array}$ & $\begin{array}{l}\mathrm{U} \\
\mathrm{K}\end{array}$ & $\begin{array}{l}\mathrm{DB}, \\
\mathrm{CO}, \\
\mathrm{R}, \mathrm{Pl}\end{array}$ & 12 & $\begin{array}{l}\text { Healthy } \\
\text { Older }\end{array}$ & 64 & 6 & 9.6 & BJ & $\begin{array}{l}\mathrm{N} \\
\mathrm{D}- \\
\mathrm{BJ}\end{array}$ & & & KVIP, SS, NR & $\mathrm{NO}$ & 3 \\
\hline $\begin{array}{l}\text { Leffer } \\
\text { ts, } \\
2015\end{array}$ & $\begin{array}{c}\text { US } \\
\text { A }\end{array}$ & $\begin{array}{l}\mathrm{DB}, \\
\mathrm{CO}, \\
\mathrm{R}, \mathrm{Pl}\end{array}$ & 20 & $\begin{array}{l}\text { Healthy } \\
\text {, Young }\end{array}$ & 23 & $\begin{array}{l}2 \\
0\end{array}$ & $6.5-7.0$ & BJ & $\begin{array}{l}\mathrm{N} \\
\mathrm{D}- \\
\mathrm{BJ}\end{array}$ & & 245 & $\begin{array}{c}\text { MR, ER, DV, } \\
\text { AST, CRT, } \\
\text { MZ, CPT, } \\
\text { GNG }\end{array}$ & YES & 3 \\
\hline $\begin{array}{l}\text { Rattra } \\
\text { y, } \\
2015^{a}\end{array}$ & $\begin{array}{c}\mathrm{Au} \\
\text { str } \\
\text { ali } \\
\mathrm{a}\end{array}$ & $\begin{array}{l}\mathrm{DB}, \\
\mathrm{CO}, \\
\mathrm{R}, \mathrm{Pl}\end{array}$ & 12 & $\begin{array}{l}\text { Healthy } \\
\text {, Young }\end{array}$ & - & - & 12 & $\mathrm{BJ}$ & $\bar{N}$ & $120 \mathrm{~min}$ & - & CST & YES & - \\
\hline $\begin{array}{l}\text { Shann } \\
\text { on, } \\
2017\end{array}$ & $\begin{array}{l}\mathrm{U} \\
\mathrm{K}\end{array}$ & $\begin{array}{l}\mathrm{DB}, \\
\mathrm{CO}, \\
\mathrm{R}, \mathrm{Pl}\end{array}$ & 10 & $\begin{array}{l}\text { Healthy } \\
\text {, Young }\end{array}$ & 23 & $\begin{array}{l}1 \\
0\end{array}$ & & & $\begin{array}{l}\mathrm{N} \\
\mathrm{D}- \\
\mathrm{BJ}\end{array}$ & $175 \mathrm{~min}$ & 23.9 & $\begin{array}{c}\text { SST, AST, } \\
\text { RVIP }\end{array}$ & YES & 3 \\
\hline $\begin{array}{l}\text { Sheph } \\
\text { erd, } \\
2015^{\text {a }}\end{array}$ & $\begin{array}{l}\mathrm{U} \\
\mathrm{K}\end{array}$ & $\begin{array}{l}\mathrm{DB}, \\
\mathrm{CO}, \\
\mathrm{R}, \mathrm{Pl}\end{array}$ & 48 & T2DM & $\begin{array}{c}63 . \\
3\end{array}$ & 3 & 6.4 & $\mathrm{BJ}$ & $\begin{array}{l}\mathrm{N} \\
\mathrm{D}- \\
\mathrm{BJ}\end{array}$ & 4 days & 30.1 & SRT, SM, CST & $\mathrm{NO}$ & \\
\hline $\begin{array}{l}\text { Thom } \\
\text { pson, } \\
2015 \\
\end{array}$ & $\begin{array}{l}\mathrm{U} \\
\mathrm{K}\end{array}$ & $\begin{array}{l}\mathrm{DB}, \\
\mathrm{CO}, \\
\mathrm{R}, \mathrm{Pl}\end{array}$ & 16 & Healthy & & 1 & 2.8 & BJ & $\begin{array}{l}\mathrm{N} \\
\mathrm{D}- \\
\mathrm{BJ} \\
\end{array}$ & 7 days & 24.6 & CST, DRT & YES & 3 \\
\hline $\begin{array}{l}\text { Thom } \\
\text { pson, } \\
2014\end{array}$ & $\begin{array}{l}\mathrm{U} \\
\mathrm{K}\end{array}$ & $\begin{array}{l}\mathrm{DB}, \\
\mathrm{CO}, \\
\mathrm{R}, \mathrm{Pl}\end{array}$ & 16 & & & $\frac{1}{6}$ & 5 & BJ & $\begin{array}{c}\mathrm{B} \\
\mathrm{CJ} \\
+ \\
\mathrm{AJ}\end{array}$ & $90 \mathrm{~min}$ & 24.1 & RVIP, CST & YES & 3 \\
\hline $\begin{array}{l}\text { Thom } \\
\text { pson, } \\
2016\end{array}$ & $\begin{array}{l}\mathrm{U} \\
\mathrm{K}\end{array}$ & $\begin{array}{l}\mathrm{DB}, \\
\mathrm{CO}, \\
\mathrm{R} . \mathrm{r}\end{array}$ & & $\begin{array}{l}\text { Healtiı } \\
\text {, Young }\end{array}$ & 24 & $\begin{array}{l}3 \\
6\end{array}$ & 6.4 & BJ & $\begin{array}{l}\mathrm{N} \\
\mathrm{D}- \\
\mathrm{BJ} \\
\end{array}$ & 5 days & 24.6 & CST & YES & 3 \\
\hline $\begin{array}{l}\text { Vanh } \\
\text { atalo, } \\
2016^{a}\end{array}$ & $\begin{array}{l}U \\
K\end{array}$ & $\mathrm{R}, \mathrm{P}_{1}^{\prime}$ & & $\begin{array}{l}\text { Healthy } \\
\text { Older }\end{array}$ & 73 & $\begin{array}{l}1 \\
0\end{array}$ & 12 & $\overline{\mathrm{BJ}}$ & $\begin{array}{l}\mathrm{N} \\
\mathrm{D}- \\
\mathrm{BJ}\end{array}$ & 10 days & 25 & RVIP & $\mathrm{NO}$ & - \\
\hline $\begin{array}{l}\text { Wight } \\
\text { man, } \\
2015\end{array}$ & $\mathrm{~K}$ & $\begin{array}{l}\mathrm{LB}, \\
\mathrm{R} / \mathrm{Pl}\end{array}$ & 40 & $\begin{array}{l}\text { Healthy } \\
\text {, Young }\end{array}$ & 21 & $\begin{array}{l}1 \\
2\end{array}$ & 5.5 & $\mathrm{BJ}$ & $\begin{array}{c}\mathrm{B} \\
\mathrm{CJ} \\
+ \\
\mathrm{AJ} \\
\end{array}$ & $90 \mathrm{~min}$ & 24 & $\begin{array}{l}\text { SS, RVIP, } \\
\text { MFT }\end{array}$ & $\mathrm{NO}$ & 3 \\
\hline
\end{tabular}

BCJ+AJ blackcurrant cordial JUICE and apple juice; BMI, body mass index; CAD, coronary artery diseases; CO, crossover; Conc, concentration; DB, double-blind; NF-C, nitrite free capsules; P, Parallel; Pl, placebo-controlled; R, Randomized SB, single-blind; SN, Sociium Nitrite; SP, spinach T2DM, type 2 diabetes; UB, non-blind. SS, Serial Subtractions, RVIP, Rapid Visual Information Processing; MFT, Mental Fatigue Test; CST, Colour Stroop Test; SRT, Simple Reaction Time; SM, Shape Memory; DRT, Decision Reaction Time; SM, Spatial Memory ; DV, Digit Vigilance ; CRT, Choice Reaction Time; NWM, Numeric Working Memory; DWR, Delayed Work Recognition ; AST, Attention Switching Task; SST, Spatial Span Task; TMT-A, Trail Making Tests A; TMT-B, Trail Making Test-B; NR, Number Recall; MR, memory recognition; ER, Emotion Recognition; VS-1, Visual Interference; VB-1, Verbal Interference; MZ, Maze, CPT, Continuous Performance Test; GNG, Go/No-Go. ${ }^{\text {a }}$ These are abstracts and the quality assessment was not performed. 
Table 2: Characteristics of the studies included in the systematic review and meta-analysis of the effects of dietary nitrate/nitrite on cerebral blood flow

\begin{tabular}{|c|c|c|c|c|c|c|c|c|c|c|c|c|c|c|c|c|}
\hline $\begin{array}{l}\text { Auth } \\
\text { or } \\
\text { (year } \\
\text { ) }\end{array}$ & $\begin{array}{l}\text { Co } \\
\text { unt } \\
\text { ry }\end{array}$ & $\begin{array}{l}\text { Stud } \\
\text { y } \\
\text { Desi } \\
\text { gn }\end{array}$ & $\begin{array}{c}\mathrm{Sa} \\
\mathrm{mpl} \\
\mathrm{e} \\
\text { Size }\end{array}$ & $\begin{array}{c}\text { Healt } \\
\text { h } \\
\text { Statu } \\
\text { s }\end{array}$ & $\begin{array}{c}\mathrm{Ag} \\
\mathrm{e} \\
\text { (ye } \\
\text { ars) }\end{array}$ & $\begin{array}{l}\text { M } \\
\text { al } \\
\text { es }\end{array}$ & $\begin{array}{c}\text { Nitrate } \\
\text { Dose } \\
(\mathrm{mmol} / \mathrm{d} \\
\text { ay) }\end{array}$ & $\begin{array}{c}\text { Type } \\
\text { of } \\
\text { Interve } \\
\text { ntion }\end{array}$ & $\begin{array}{c}\mathrm{Pl} \\
\mathrm{ac} \\
\mathrm{eb} \\
\mathrm{o}\end{array}$ & $\begin{array}{l}\text { Duratio } \\
\mathrm{n} \text { of } \\
\text { interven } \\
\text { tion }\end{array}$ & $\begin{array}{l}\text { Base } \\
\text { line } \\
\text { BMI } \\
(\mathrm{Kg} / \\
\left.\mathrm{m}^{2}\right)\end{array}$ & $\begin{array}{c}\text { CBF } \\
\text { Assess } \\
\text { ment }\end{array}$ & $\begin{array}{c}\text { Exerc } \\
\text { ise } \\
\text { Testin } \\
\mathrm{g} ?\end{array}$ & $\begin{array}{l}\text { Eff } \\
\text { ect } \\
\text { at } \\
\text { res } \\
\text { tin }\end{array}$ & $\begin{array}{l}\text { Eff } \\
\text { ect } \\
\text { in } \\
\text { sti } \\
\text { mu }\end{array}$ & $\begin{array}{l}\mathrm{J} \\
\mathrm{a} \\
\mathrm{d} \\
\mathrm{a} \\
\mathrm{c}\end{array}$ \\
\hline $\begin{array}{l}\text { Aam } \\
\text { and, } \\
2013\end{array}$ & $\begin{array}{l}\text { De } \\
\text { nm } \\
\text { ark }\end{array}$ & $\begin{array}{c}\mathrm{DB}, \\
\mathrm{Pl}, \\
\mathrm{CO}, \\
\mathrm{R}\end{array}$ & 20 & $\begin{array}{l}\text { Healt } \\
\text { hy, } \\
\text { Youn } \\
\text { g }\end{array}$ & 25 & $\begin{array}{l}2 \\
0\end{array}$ & 7.7 & SNA & $\begin{array}{l}\mathrm{N} \\
\mathrm{F}- \\
\mathrm{S}\end{array}$ & 3 days & - & ASL & & $\overline{N^{\top} \mathrm{O}}$ & & 2 \\
\hline $\begin{array}{l}\text { Bond } \\
2013\end{array}$ & $\begin{array}{c}\text { US } \\
\text { A }\end{array}$ & $\begin{array}{l}\mathrm{Pl}, \\
\mathrm{CO}, \\
\mathrm{R}\end{array}$ & 12 & $\begin{array}{l}\text { Healt } \\
\text { hy, } \\
\text { Youn }\end{array}$ & 20 & - & $5-6$ & BJ & OJ & $120 \mathrm{~min}$ & 24.4 & & YES & $\begin{array}{l}\text { Po } \\
\text { siti } \\
\text { ve }\end{array}$ & $\begin{array}{c}\text { Pos } \\
\text { itiv } \\
\text { e }\end{array}$ & 1 \\
\hline $\begin{array}{l}\text { Chiri } \\
\text { nos, } \\
2017\end{array}$ & $\begin{array}{c}\text { US } \\
\text { A }\end{array}$ & $\begin{array}{l}\text { DB, } \\
\text { CO, } \\
\text { R, Pl }\end{array}$ & 17 & $\begin{array}{c}\mathrm{HFp} \\
\mathrm{EF}\end{array}$ & 65 & $\begin{array}{l}1 \\
4\end{array}$ & 12.9 & BJ & $\begin{array}{l}\text { N } \\
\text { D- } \\
\text { BJ }\end{array}$ & $150 \mathrm{~min}$ & & & NO & $\begin{array}{l}\text { Po } \\
\text { siti } \\
\text { ve }\end{array}$ & - & 4 \\
\hline $\begin{array}{l}\text { Curry } \\
2016\end{array}$ & $\begin{array}{c}\text { US } \\
\text { A }\end{array}$ & $\begin{array}{c}\mathrm{Pl}, \\
\mathrm{CO}, \\
\mathrm{R}\end{array}$ & 10 & $\begin{array}{l}\text { Healt } \\
\text { hy, } \\
\text { Youn } \\
\sigma\end{array}$ & 20 & - & 24.2 & BJ & $\mathrm{PI}$ & $120 \mathrm{mi} i$ & 23.5 & MCAV & YES & $\begin{array}{l}\text { Po } \\
\text { siti } \\
\text { ve }\end{array}$ & $\begin{array}{c}\text { Pos } \\
\text { itiv } \\
\text { e }\end{array}$ & 1 \\
\hline $\begin{array}{l}\text { Leffe } \\
\text { rts, } \\
2015\end{array}$ & $\begin{array}{c}\text { US } \\
\text { A }\end{array}$ & $\begin{array}{l}\text { DB, } \\
\text { CO, } \\
\text { R, Pl }\end{array}$ & 20 & $\begin{array}{l}\text { Healt } \\
\text { hy, } \\
\text { Youn } \\
\text { g }\end{array}$ & 23 & $\begin{array}{l}2 \\
0\end{array}$ & $6.5-75$ & & $\begin{array}{l}\text { D- } \\
\text { BJ }\end{array}$ & $120 \mathrm{~min}$ & 24.6 & MCAV & YES & $\begin{array}{c}\text { No } \\
\text { cha } \\
\text { ng } \\
\mathrm{e}\end{array}$ & $\begin{array}{l}\text { No } \\
\text { cha } \\
\text { nge }\end{array}$ & 3 \\
\hline $\begin{array}{l}\text { Presl } \\
\text { ey, } \\
2011\end{array}$ & $\begin{array}{c}\text { US } \\
\text { A }\end{array}$ & $\begin{array}{c}\mathrm{R}, \mathrm{C} \\
\mathrm{O}\end{array}$ & 16 & $\begin{array}{l}\text { Healt } \\
\text { hy, } \\
\text { Old }\end{array}$ & $\geq$ & & & $\begin{array}{c}\text { High } \\
\text { nitrate } \\
\text { diet }\end{array}$ & $\begin{array}{c}\text { Lo } \\
\text { w } \\
\text { nit } \\
\text { rat } \\
\text { e } \\
\text { di } \\
\text { et }\end{array}$ & 2 days & - & ASL & $\mathrm{NO}$ & $\begin{array}{c}\text { Po } \\
\text { siti } \\
\text { ve } \\
\text { (re } \\
\text { gin } \\
\text { al } \\
\text { cer } \\
\text { ebr } \\
\text { al } \\
\text { per } \\
\text { fus } \\
\text { ion } \\
\text { ) }\end{array}$ & - & 2 \\
\hline $\begin{array}{l}\text { Rattr } \\
\text { ay, } \\
2015^{\text {a }}\end{array}$ & $\begin{array}{c}\mathrm{Au} \\
\text { sur } \\
\text { ali } \\
\mathrm{a}\end{array}$ & $\begin{array}{l}\mathrm{DE} \\
\mathrm{CO}, \\
\text { R. } \mathrm{F1}\end{array}$ & & $\begin{array}{l}\text { Healt } \\
\text { hy, } \\
\text { Youn } \\
\text { g }\end{array}$ & - & - & 13 & BJ & $\begin{array}{l}\mathrm{N} \\
\mathrm{D}- \\
\mathrm{BJ}\end{array}$ & $120 \mathrm{~min}$ & - & MCAV & YES & $\begin{array}{l}\text { Po } \\
\text { siti } \\
\text { ve }\end{array}$ & - & - \\
\hline $\begin{array}{l}\text { The } \\
\text { nipso } \\
\text { n, } \\
2014\end{array}$ & $\begin{array}{l}\mathrm{U} \\
\mathrm{K}\end{array}$ & $\begin{array}{l}\mathrm{D} 3, \\
\mathrm{CO}, \\
\mathrm{R}, \mathrm{Pl}\end{array}$ & 16 & $\begin{array}{l}\text { Healt } \\
\text { hy, } \\
\text { Youn } \\
\text { g }\end{array}$ & 24 & $\begin{array}{l}1 \\
6\end{array}$ & 5 & BJ & $\begin{array}{c}\mathrm{B} \\
\mathrm{CJ} \\
+ \\
\mathrm{AJ} \\
\end{array}$ & $90 \mathrm{~min}$ & 24.1 & NIRS & YES & $\begin{array}{l}\text { Po } \\
\text { siti } \\
\text { ve }\end{array}$ & $\begin{array}{c}\text { Pos } \\
\text { itiv } \\
\text { e }\end{array}$ & 3 \\
\hline $\begin{array}{l}\text { Wigh } \\
\text { tman, } \\
2015\end{array}$ & $\begin{array}{l}\mathrm{U} \\
\mathrm{K}\end{array}$ & $\begin{array}{c}\mathrm{P}, \\
\mathrm{DB}, \\
\mathrm{R}, \mathrm{Pl}\end{array}$ & 40 & $\begin{array}{l}\text { Healt } \\
\text { hy, } \\
\text { Youn } \\
\text { g }\end{array}$ & 21 & $\begin{array}{l}1 \\
2\end{array}$ & 5.5 & BJ & $\begin{array}{c}\text { B } \\
\text { CJ } \\
+ \\
\text { AJ }\end{array}$ & $90 \mathrm{~min}$ & 24 & NIRS & NO & $\begin{array}{l}\text { Po } \\
\text { siti } \\
\text { ve }\end{array}$ & $\begin{array}{l}\mathrm{Ne} \\
\text { gat } \\
\text { ive }\end{array}$ & 3 \\
\hline
\end{tabular}

BCJ+AJ, blackcurrant cordial JUICE and apple juice; OJ, Orange juice; SN, Sodium Nitrate; NF-S, Nitrate free solution; BJ, Beetroot juice; ND-BJ, Nitrate depleted beetroot juice BMI, body mass index; CO, crossover; DB, double-blind; NF-C, nitrite free capsules; P, Parallel; Pl, placebo-controlled; R, Randomized SB, single-blind; ASL, Arterial spin labelling; CVRI, Cerebrovascular resistance index; SBP, Systolic blood pressure; TVR, Total vascular resistance; MCAV, Middle cerebral artery blood flow velocity; HFpEF, Heart failure preserved left ventricular ejection fraction; CCID, Carotid characteristic impedance, dynes; CCSA, Carotid cross-sectional area; CBVRD, Carotid bed vascular resistance, dynes. ${ }^{a}$ This is an abstract and the quality assessment was not performed. 
Table 3: Meta-regression analysis to evaluate whether age, BMI, dose of nitrate and duration of the intervention modified the effects of nitrate/ nitrite supplementation on cognitive and cerebral blood flow

\begin{tabular}{|c|c|c|c|c|}
\hline & Slope $(\beta)$ & SE & $Q(d f)$ & $\boldsymbol{P}$ \\
\hline \multicolumn{5}{|c|}{ Cognitive function $(n=13)$} \\
\hline Age (years) & -0.002 & 0.003 & $0.92(1)$ & \\
\hline BMI $\left(\mathrm{kg} / \mathrm{m}^{2}\right)$ & -0.02 & 0.02 & $1.38(1)$ & 0.23 \\
\hline Dose (mg/day) & 0.002 & 0.004 & $0.22(1)$ & 0.63 \\
\hline Duration (hours) & 0.0005 & 0.0002 & 3.20 (i) & 0.07 \\
\hline Jadad & 0.30 & 0.18 & $2.85 \overline{(1)}$ & 0.09 \\
\hline \multicolumn{5}{|c|}{ Resting CBF $(n=9)$} \\
\hline Age (years) & 0.001 & 0.006 & $0.09(1)$ & 0.98 \\
\hline $\operatorname{BMI}\left(\mathrm{kg} / \mathrm{m}^{2}\right)$ & 0.02 & 0.032 & $0.58(1)$ & 0.45 \\
\hline Dose (mg/day) & -0.02 & 0.023 & $0.43(1)$ & 0.51 \\
\hline Duration (hours) & -0.001 & 0.0006 & $5.07(1)$ & 0.02 \\
\hline Jadad & & 0.13 & $0.06(1)$ & 0.79 \\
\hline
\end{tabular}

BMI, Body Mass Index; SE, stanidard error; CBF, cerebral blood flow. 